\title{
Soil cadmium extraction in Chinese cabbage and cabbage intercropping
}

\author{
Jiayue Wan ${ }^{1}$ (D) Hexigeduleng Bao ${ }^{1}$ (D) Lihong Huang ${ }^{1}$ (D) Yanfei Ding ${ }^{1}$ (ID \\ Zhixiang Chen ${ }^{1,2}$ (D) Cheng Zhu ${ }^{1 *}$ (iD
}

${ }^{1}$ Key Laboratory of Marine, Food Quality and Hazard Controlling Technology of Zhejiang Province, College of Life Sciences, China Jiliang University, 310018, Hangzhou, China. E-mail: pzhch@cjlu.edu.cn. "Corresponding author. ${ }^{2}$ Department of Botany and Plant Pathology, Purdue University, West Lafayette, Indiana, United States.

ABSTRACT: Toxic metals contamination of soil has become a serious problem in recent years. In this study, Chinese cabbage (a relatively high-accumulator of cadmium (Cd)) and cabbage (a relatively low-accumulator of $C d$ ) were cultured in monoculture and in intercropping in the Cd-contaminated soil, to evaluate the effect of intercropping on the alteration of Cd extraction. Both the pot experiments and field experiments indicated that intercropping increased the Cd extraction by Chinese cabbage and decreased the Cd extraction by cabbage. Thus, Cd extraction was advanced while safe production was obtained. Further pot experiment was conducted to investigate the alterations of soil Cd fractions, soil pH, and soil enzyme activities to reveal their possible relationship with Cd extraction between different planting patterns. Results revealed that three individual Chinese cabbages in one intercropping pot played the same effect on alteration of these factors as six individual Chinese cabbages in one monoculture pot. The intercropping increased Cd extraction by Chinese cabbage and decreased Cd extraction by cabbage, probably by influencing mechanisms such as soil enzyme activities (especially the urease activity) in the cultivation system. Effect of intercropping on Cd accumulation is an important issue in cultivation of vegetables in potentially contaminated land.

Key words: toxic metals, vegetables, phytoextraction, safe production.

Extração de cádmio no solo em repolho chinês e consorciação de repolho

RESUMO: A contaminação do solo por metais tóxicos tornou-se um problema grave nos últimos anos. Neste estudo, dois tipos de repolhos, o repolho chinês (maior acumulador de cádmio (Cd)) e o repolho comum (menor acumulador de Cd) foram cultivados em monocultivo e em consórcio, em solo contaminado com esse metal, para avaliar o efeito do consórcio na extração de Cd do solo. Os experimentos em vasos de campo indicaram que o consórcio aumentou a extração desse metal pelo repolho chinês e diminuiu a extração pelo repolho comum. Assim, aumentou a extração de Cd do solo, proporcionando segurança alimentar. Outro experimento em vaso foi conduzido para investigar as alterações das frações de $\mathrm{Cd}$ do solo, o $\mathrm{pH}$ do solo e atividades enzimáticas do solo, para revelar possíveis efeitos na extração desse metal entre os sistemas de plantio. Os resultados do experimento em vaso revelaram que três repolhos da china, em cultivo consorciado, proporcionaram o mesmo efeito nessas variáveis, que os observados com seis plantas desse tipo de repolho, em monocultura. O consórcio influenciou as frações de Cd do solo devido a maior influência das hortaliças no pH do solo e nas atividades enzimáticas (especialmente a urease), resultando maior extração de Cd pelo repolho chinês e menor pelo repolho comum.

Palavras-chave: metais tóxicos, produtos hortícolas, fitoextração, seguranca alimentar.

\section{INTRODUCTION}

The global industry has developed drastically since the last century, with a large amount of toxic metals released into the environment. Toxic metals cause serious environmental pollution and compromise human health. Research data from the Country Resource Department of China in 2009 showed that more than $10 \%$ of plantation land had been contaminated by toxic metals. Crops harvested from the contaminated soil contain excess toxic metals which may subsequently enter the human body through food chain, resulting in serious human health concerns (JAISHANKAR et al., 2014.; FASAHAT, 2014.; REN et al., 2003). Cadmium (Cd) is one of the toxic metals which threatened both environment and human health. Researches confirmed that $\mathrm{Cd}$ exposure causes damage to the kidneys, and longterm exposure will damage the skeleton (JARUP, 2003). Because toxic metals pollution is not removable and is difficult to identify, the remediation process is extremely time-consuming, resulting in 
even more deleterious effects. Thus, it is urgent to develop methods of remediation of contaminated soil or decrease $\mathrm{Cd}$ extraction by crops for safe food production in contaminated soil.

Agricultural intercropping is often used to increase harvest, efficient use for nitrogen, and antidisease ability (YUAN et al., 1998; SZUMIGALSKI et al., 2006; DAMICONE et al., 2007). Moreover, data from other studies has indicated that intercropping also influence toxic metals extraction. For example, corn intercropped with legumes can significantly reduce the $\mathrm{Pb}$ content of soil (HUANG et al., 2006). Rice and wheat intercropped resulted in decreased uptake of Cd in shoots of rice (LI ${ }^{1}$ et al. 2004; WU et al., 2003; XIN et al. 2017). Thus, intercropping of diverse plant species may alter the toxic metals extraction ability, resulting in enhanced remediation of contaminated soil or decreased extraction of toxic metals by crops to gain safe food production.

In this study, Chinese cabbage and cabbage which are common in the Yangtze River Delta were selected to evaluate the alteration of $\mathrm{Cd}$ extraction between monoculture and intercropping. We hypothesized that intercropping exhibited discrepant alteration of $\mathrm{Cd}$ extraction by the two plants species due to their different $\mathrm{Cd}$ extraction ability. Our results provided a reference for further exploration of the effects of intercropping on the absorption of toxic metals by plants.

\section{MATERIALS AND METHODS}

Experiments were carried out first in pots, to evaluate the Cd extraction, then in field, to verify results of pot experiment. Finally, experiments were carried out to study the mechanisms of such alteration.

\section{Pot experiment}

Plants and soil

The pot experiment was conducted in the city of Hangzhou, Zhejiang province, China, from March to July. Two types of plant species were used in the experiment (1) a Chinese cabbage specie (Brassica chinensis L.), and (2) a cabbage specie
(Brassinca oleracea var. capitata.). The reasons we chose these two plant species are because of their (1) short life cycle; (2) relatively high accumulation of toxic metals. Seeds of these two species were purchased from the Hangzhou Seeds Company.

Soil for the pot experiment was collected from the surface layer $(0-20 \mathrm{~cm})$ of an unpolluted paddy field in Hangzhou city, and it was a reddish clayey paddy soil (Inceptisol, USDA soil taxonomy) with slightly acidic reaction, which developed on the quaternary red earth and is widely distributed over South China (SCHAEFER et al., 2007). The soil physical and chemical properties were measured before planting (Table 1). For analysis of the pot experiment, the soil was sieved using a 2-mm grid sieve and air dried. Particle size distribution was determined by the pipette method as described previously (ABAYNEH et al., 2007). It included $21 \%$ sand, $45 \%$ silt, $34 \%$ clay, and a background total $\mathrm{Cd}$ concentration of $0.18 \mathrm{mg}$ $\mathrm{kg}^{-1}$. According to our pre-experiment, we chose 3.0 $\mathrm{mg} \mathrm{kg} \mathrm{kg}^{-1}$ as the target concentration of soil $\mathrm{Cd}$. We planted 20 different types of crops (20 varieties of Chinese cabbages and cabbages including the two used in the following experiments) on four kinds of soils (the same soil as used in the following pot experiment) with the following Cd concentrations: 0.3, 1.0, 3.0, and $10.0 \mathrm{mg} \mathrm{kg}^{-1}$. We found that when below or equal to 3.0 $\mathrm{mg} \mathrm{kg} \mathrm{kg}^{-1}$, the crop growth is not affected by pollution level. Cadmium treated soil was prepared by manually mixing with $\mathrm{CdSO}_{4}$ solution and equilibrated for 30 days (LIN et al., 2014; LIU et al., 2017). To ensure Cd homogeneity, the soil was turned every 5 days during 30 days. Before planting, the $\mathrm{Cd}$ level was determined to be $2.62 \mathrm{mg} \mathrm{kg}^{-1}$. This content was total $\mathrm{Cd}$ (all soil samples were digested with a mixture of $\mathrm{HNO}_{3}$ $\mathrm{HClO}_{4}(\mathrm{~V} / \mathrm{V}=4 / 1)$ until completely clear, according to the national standards (GB 5009.15-2014)), and Cd concentration in the extracts was determined by atomic absorption spectrometry.

\section{Experimental procedures}

Three types of treatments were performed:

(1) Chinese cabbage monoculture, (2) cabbage monoculture, and (3) intercropping of these species.

Table 1 - Physical and chemical properties of soil used in pot experiment.

\begin{tabular}{|c|c|c|c|c|c|c|c|c|}
\hline $\mathrm{pH}$ & Organic matter & Total nitrogen & Available P & Available K & Available Cd & Sand & Silt & Clay \\
\hline 5.76 & $18.3 \mathrm{~g} \mathrm{~kg}^{-1}$ & $1.14 \mathrm{~g} \mathrm{~kg}^{-1}$ & $12.3 \mathrm{mg} \mathrm{kg}^{-1}$ & $114 \mathrm{mg} \mathrm{kg}^{-1}$ & $0.18 \mathrm{mg} \mathrm{kg}^{-1}$ & $21 \%$ & $45 \%$ & $34 \%$ \\
\hline
\end{tabular}


Experiments were replicated six times in a randomized complete block design.

Twenty $\mathrm{kg}$ of soil was added to one plastic pot $(40 \times 20 \times 20 \mathrm{~cm})$, in which six individual plants were cultured. The pots were set up in no protected environment under a glass shelter. Before cultivation, seeds were germinated in soil mixed with vermiculite and peat $(\mathrm{V} / \mathrm{V}=1 / 1)$. Seedlings were transferred to the prepared pots 24 days later. Soils were maintained at $80 \%$ water holding capacity by regular applications of deionized water. Plants were harvested two months later, and rhizosphere soil was collected by shaking the roots. Soils of unplanted pots were collected at the same time.

\section{Sampling and measurements}

Plant samples were washed thoroughly with tap water and then distilled water. Plants were divided into shoots and roots, and then weighed. Plant tissues were oven-dried at $70{ }^{\circ} \mathrm{C}$ until constant weight, and weighted. The oven-dried samples were ground with a stainless-steel grinder. Soil samples were air-dried, crushed, and passed through a $0.082 \mathrm{~mm}$ sieve. All plant samples were digested with a mixture of $\mathrm{HNO}_{3}-$ $\mathrm{HClO}_{4}$ as same as the soil samples. Cadmium levels in plants and soils, as well as levels of five $\mathrm{Cd}$ fractions in soil were extracted according the sequential extraction method proposed by TESSIER et al. (1979) and determined by atomic absorption spectrometry.

Soil $\mathrm{pH}$ was determined using a glass electrode in soil/distilled water mixture of 2:5 $(\mathrm{w} / \mathrm{v})$. Acid phosphatase activity determination was performed as described by ELSAS (1994). Catalase activity determination was performed as described by JOHNSON et al (1964), and urease activity determination was performed as described by NANNIPIERI (1994).

Field experiment

Study site

The field site was approximately $700 \mathrm{~m}^{2}$, located in Wenling Township, Taizhou City, Zhejiang province (121 $37^{\prime}$ 'East Longitude and $28^{\circ} 37^{\prime}$ North Latitude). The area is in the subtropical monsoon climate and has an average annual temperature of $16.1^{\circ} \mathrm{C}$ and annual rainfall of $1441.9 \mathrm{~mm}$, and the soil was a reddish clayey paddy soil (Inceptisol, USDA soil taxonomy) the same as pot soil (FAO-Unesco, 1973). We measured the soil physical and chemical properties before planting (Table 2). For analysis of the field experiment, the soil was also sieved using a 2-mm grid sieve and air dried. Particle size distribution was determined by the pipette method as described previously (ABAYNEH et al., 2007). Soil used in the field experiment included $34 \%$ sand (diameter 2-0.02 mm), 43\% silt (diameter 0.02-0.002 $\mathrm{mm}$ ), $23 \%$ clay (diameter less than $0.002 \mathrm{~mm}$ ), and a $\mathrm{Cd}$ concentration of $0.88 \mathrm{mg} \mathrm{kg}^{-1}$.

\section{Experimental design}

The treatments were same as in the pot experiment. Experiments were replicated three times in a randomized complete block design. The block was $2 \times 10 \mathrm{~m}$ with $40 \mathrm{~cm}$ spacing between each other. There were 3 rows with $30 \mathrm{~cm}$ line spacing in each block. Before cultivation, seeds were germinated in soil mixed with vermiculite and peat $(\mathrm{V} / \mathrm{V}=1 / 1)$. Seedlings were transferred to the experimental field in the middle ten days of April and harvested in the first ten days of July.

\section{Sampling and measurements}

Five random samples were taken from each plot, and rhizosphere soils were collected at the same time. Sample treatments were the same as the pot experiment. The Cd levels in shoots and roots of plants, and in soils were determined according to the same methods.

\section{Statistical analysis}

In order to detect a significant difference in the data, analysis of variance (ANOVA) was performed, followed by the least significant difference test $(\mathrm{P} \leq 0.05)$.

\section{RESULTS}

Intercropping caused increased extraction of $\mathrm{Cd}$ by Chinese cabbage, and decreased extraction by cabbage In the pot experiment, $\mathrm{Cd}$ levels of soils in non-planted pots were determined to be 2.62

Table 2 - Physical and chemical properties of soil in field experiment.

\begin{tabular}{|c|c|c|c|c|c|c|c|c|}
\hline $\mathrm{pH}$ & Organic matter & Total nitrogen & Available P & Available K & Available Cd & Sand & Silt & Clay \\
\hline 5.02 & $42.8 \mathrm{~g} \mathrm{~kg}^{-1}$ & $294 \mathrm{mg} \mathrm{kg}^{-1}$ & $331 \mathrm{mg} \mathrm{kg}^{-1}$ & $110 \mathrm{mg} \mathrm{kg}^{-1}$ & $0.88 \mathrm{mg} \mathrm{kg}^{-1}$ & $34 \%$ & $43 \%$ & $23 \%$ \\
\hline
\end{tabular}

Ciência Rural, v.49, n.11, 2019. 
$\mathrm{mg} \mathrm{kg}{ }^{-1}$, while in Chinese cabbage monoculture, cabbage monoculture, and intercropping of them were determined to be $2.56,2.44$, and $2.06 \mathrm{mg} \mathrm{kg}^{-}$ ${ }^{1}$, respectively (Figure 1A). Although the decrease between monoculture and intercropping was not remarkable, the data showed slight decrease due to plants extraction.

Cd levels in both shoots and roots of Chinese cabbage were significantly higher in intercropping than in monoculture, while only in shoots of cabbage were significantly lower in intercropping than in monoculture (Figure 1B). The data indicated that intercropping caused increased extraction of $\mathrm{Cd}$ by Chinese cabbage, and decreased extraction by cabbage.

In the field experiment, $\mathrm{Cd}$ levels of soils had little alteration between non-planted soil, monoculture, and intercropping. Cd levels in both shoots and roots of Chinese cabbage were only slightly higher in intercropping than in monoculture (not markedly) (Figure 2A), while in shoots and roots of cabbage it was significantly lower and slightly lower in intercropping than in monoculture, respectively (Figure 2B). All results were generally consistent with those in our pot experiment.

\section{Levels of five Cd fractions in soil}

The Tessier sequential extraction method was used to extract five $\mathrm{Cd}$ fractions in soil: (1) exchangeable $\mathrm{Cd}$ (Figure 3A); (2) $\mathrm{Cd}$ bound to carbonates (the concentration was substantially low enough and was neglected in our experiment); (3) Cd bound to Fe-Mn oxides (Figure 3B); (4) Cd bound to organic matter (Figure 3C); and (5) residual Cd (Figure 3D).

Level of exchangeable $\mathrm{Cd}$ in soil was significantly lowered by Chinese cabbage monoculture, but not by cabbage monoculture or intercropping (Figure 3A). All the other $\mathrm{Cd}$ fractions in either monoculture or intercropping showed little difference compared with the nonplanted soil (Figure 3B-D).

\section{Effects of intercropping of vegetables on the soil PH}

In non-planted soil of pot experiment, the $\mathrm{pH}$ was determined to be 5.76, which was significantly higher than 5.49, 5.62, and 5.59 in Chinese cabbage monoculture, cabbage monoculture, and intercropping of these species, respectively (Table 3). However, the differences between the latter three planting patterns were not remarkable.

Effects of intercropping of vegetables on the soil enzyme activities

Toxic metal stress produces excess hydrogen peroxide which will cause damage to the plant. Soil catalase can promote the decomposition of excess hydrogen peroxide, mitigating the damage. However, according to our experimental data, the catalase activities in all the planted soils were not significantly compared with the non-planted soil

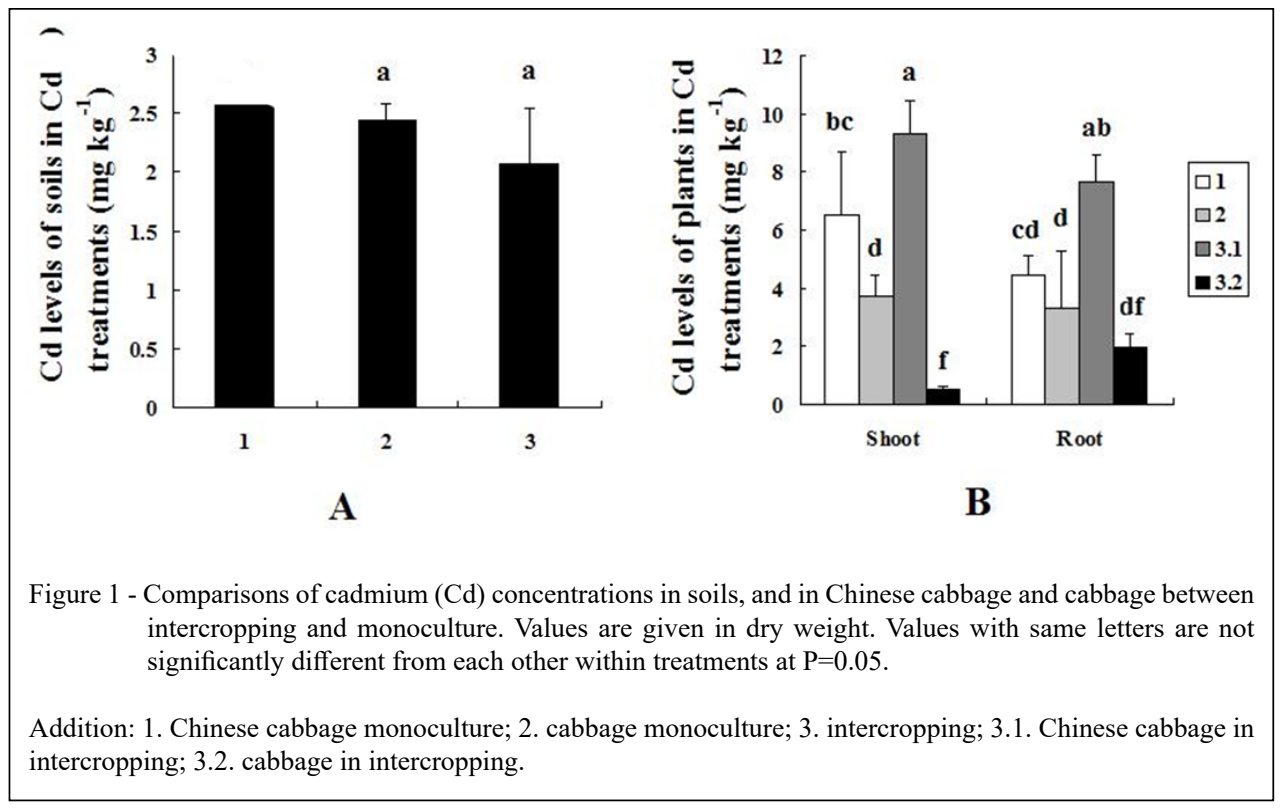

Ciência Rural, v.49, n.11, 2019. 


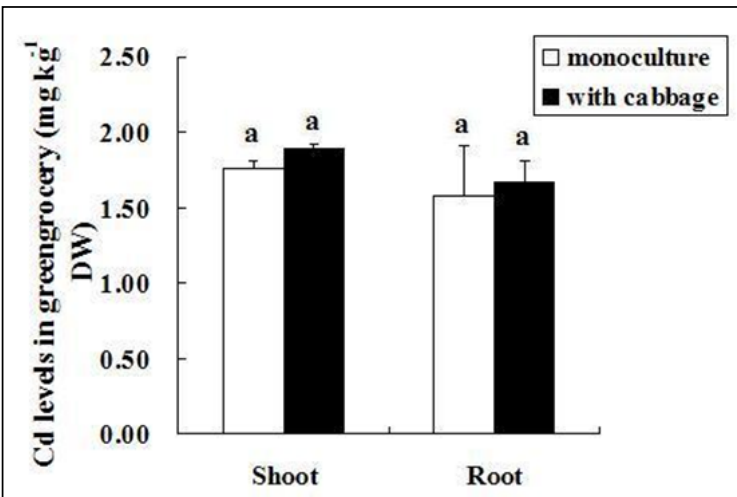

A

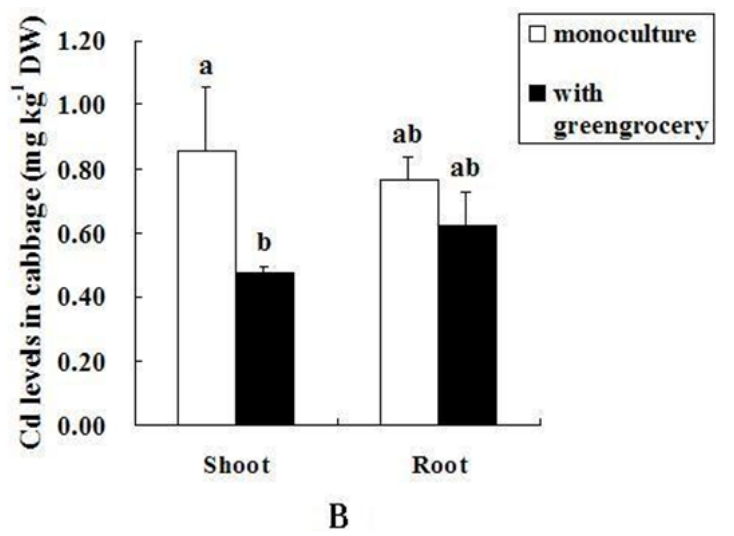

B

Figure 2 - Comparisons of cadmium (Cd) concentrations in Chinese cabbage and cabbage between intercropping and monoculture in field experiment. Values are given in dry weight. Values with same letters are not significantly different from each other within treatments at $\mathrm{P}=0.05$.

(Figure 4A). Moreover, intercropping did not cause more increase of catalase activities than monoculture.

The soil acid phosphatase functions as the promoting of the transformation of soil organic phosphorus to available forms. It can reduce the $\mathrm{Cd}$ toxic stress to plants. However, toxic metals will restrain the activity of acid phosphatase, resulting in reduced transformation of soil organic phosphorus to available forms (TYLER, 1974; LEFEBVRE et al., 1990; WANG et al., 1991). Our results showed that the soil acid phosphatase activities in all the planted soils were significantly higher than in the non-planted soil (Figure 4B). It means that the restrained activity of acid phosphatase which was caused by $\mathrm{Cd}$ was recovered to a certain extent. More soil organic phosphorus can be transformed to available forms by the higher acid phosphatase activities, which reduce the $\mathrm{Cd}$ toxic stress to plants more efficiently. However, there were no significant differences of acid phosphatase activities between the three planting patterns, suggesting that intercropping did not cause more increase of acid phosphatase activities than monoculture.

Soil urease promotes the production of plant nitrogen source-ammonia, whose activity was also restrained by toxic metals (TYLER, 1974; POLACCO et al., 1985). In our experiment, the soil urease activities in Chinese cabbage monoculture and intercropping of the two plant species were similar, and both were significantly lower than in the non-planted soil, while in cabbage monoculture were similar as in the non-planted soil (Figure 4C).
Hence, three individual Chinese cabbages in one intercropping pot showed the same influence to the soil urease activity as six individual Chinese cabbages in one monoculture pot.

\section{DISCUSSION}

In this study, our aim was to compare the effects of intercropping and monoculture on the absorption of $\mathrm{Cd}$ by vegetables, using two different planting conditions. The emphasis of pot experiment was to explore how intercropping changed the ability of crops to absorb this metal, as the experimental conditions are easier to be controlled in pot experiment, while the field experiment was more inclined to verify the applicability of intercropping in contaminated soils in agricultural practice. The soil $\mathrm{Cd}$ content used in the field experiment is lower than the soil used in the pot experiment, but both of them belong to paddy soil.

According to the national standard of China, soil environmental quality-risk control standard for soil contamination of agricultural land (GB 15618-2018), both the soils used in pot experiment $\left(2.62 \mathrm{mg} \mathrm{kg}^{-1} \mathrm{Cd}\right)$ and field experiment $\left(0.88 \mathrm{mg} \mathrm{kg}{ }^{-1} \mathrm{Cd}\right)$ belong to contaminated soils. According to the standard, the Cd content of potted soils reaches the risk intervention value of $2.0 \mathrm{mg}$ $\mathrm{kg}^{-1} \mathrm{Cd}$. The risk intervention value means that if on farmland $\mathrm{Cd}$ content is higher than this value, it is difficult to reduce the risks of exceedances through agronomic regulation, alternative planting, and other 


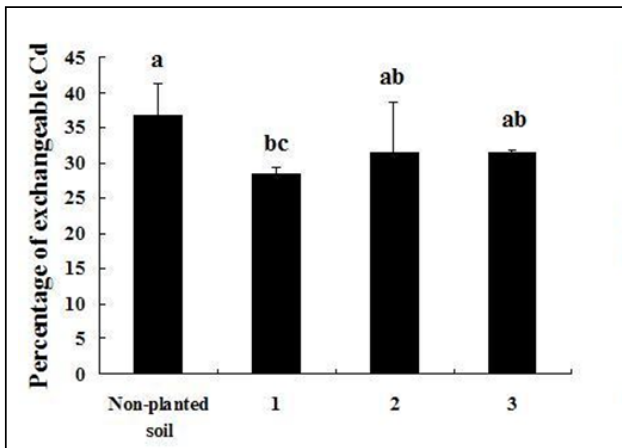

A

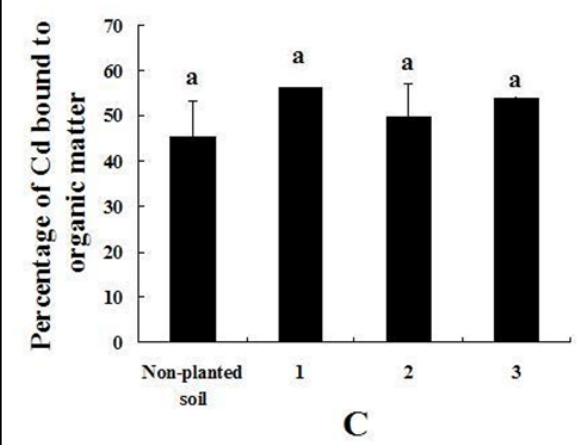

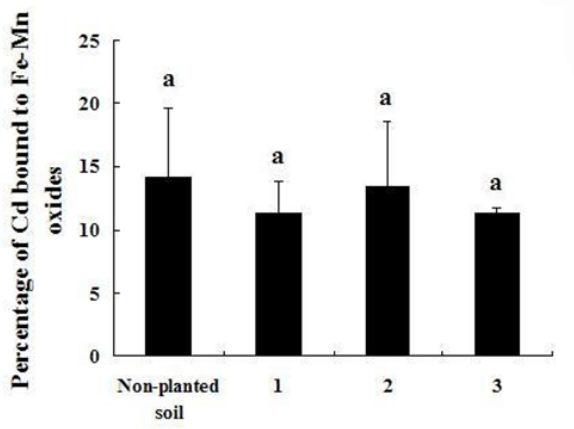

B

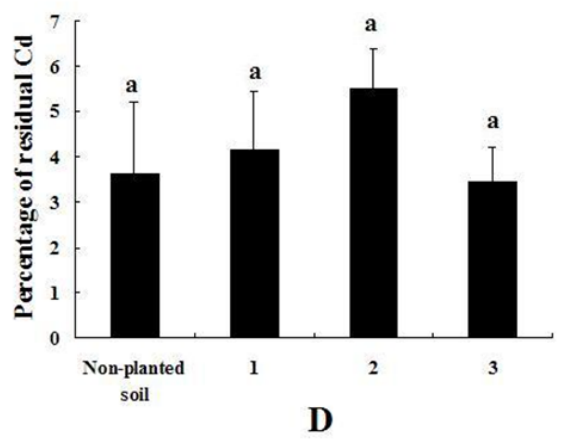

D

Figure 3 - Comparisons of cadmium (Cd) fractions in soil between intercropping and monoculture. Values with same letters are not significantly different from each other within treatments at $\mathrm{P}=0.05$.

Addition: 1. soil of Chinese cabbage monoculture; 2. soil of cabbage monoculture; 3 . soil of intercropping.

measures. Risk-based soil management strategies would be useful to lower the risks of exceedances of $\mathrm{Cd}$ in food, which is not advocated for crop cultivation. However, there are still high risks of such soils being used, since there are many places located near the mining and smelting areas, industrial areas, high toxic metal geological background areas, as well as non-uniform distribution of toxic metals in regional context (CHEN, et al., 2018). Cadmium content in field soils were lower than the risk intervention value ( $2.0 \mathrm{mg} \mathrm{kg}^{-1} \mathrm{Cd}$ ) but exceeded the risk screening value of $0.3 \mathrm{mg} \mathrm{kg}^{-1} \mathrm{Cd}$. The risk screening value means that when the content of $\mathrm{Cd}$ in a soil is higher than this value, there is a risk of exceedances, and specific investigations are needed to be made regarding food safety of farmland soil pollution. Under this contamination, there are certain safety risks, thus safe production technology is advocated.

Soil Cd adsorption and desorption capacity is related to the size of soil particles (SINGOVSZKA et al., 2015). It is considered that the larger the soil particles are, the stronger the cadmium adsorption capacity is. On the contrary, the larger the soil particles are, the weaker the desorption capacity is (YUAN et al., 2013). In our experiment, the particle size distribution of potted soil and field soil are different. Therefore, it would be inappropriate to compare the results of pot experiment directly with the field experiment. However, both our pot experiment and field experiment results showed that Cd levels in Chinese cabbage increased while in cabbage decreased when they were cultured in intercropping. Although the physical and chemical properties of the two soils have some differences, they belong to the same type of soil-paddy soil. Thus, the experimental results indicated that the same trend can be achieved by intercropping compared with monoculture in both soils, suggesting that intercropping has more general applicability under different conditions.

The $\mathrm{Cd}$ level in shoots of cabbage in intercropping were $0.54 \mathrm{mg} \mathrm{kg}^{-1} \mathrm{DW}$ in pot experiment (Figure 1B) and $0.48 \mathrm{mg} \mathrm{kg}^{-1} \mathrm{DW}$ in field experiment (Figure 2B), respectively. This level was far below 


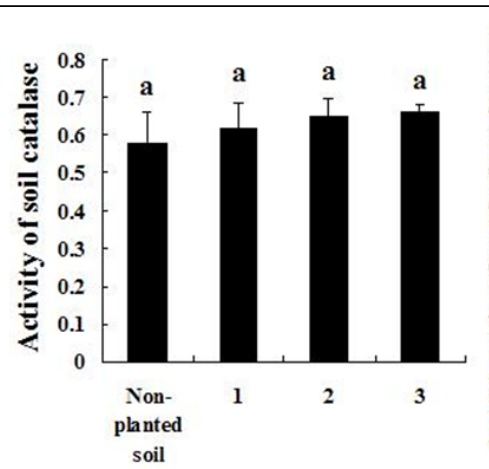

A

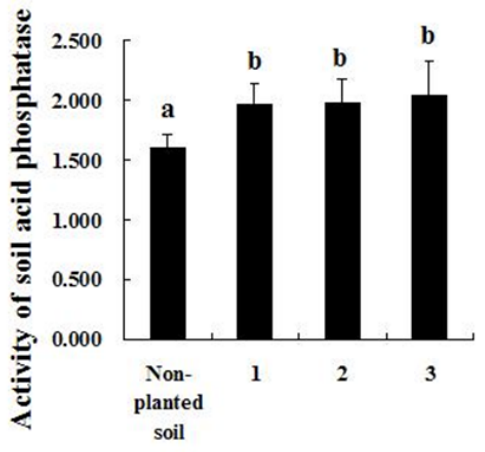

B

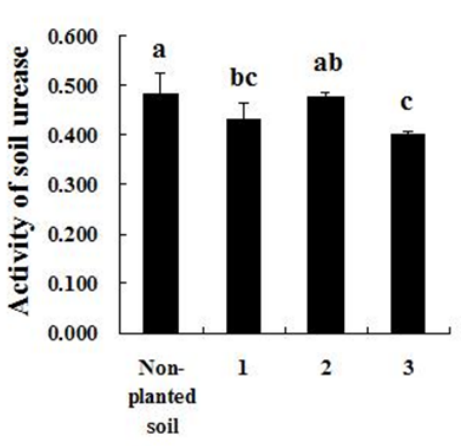

C

Figure 4 - Comparisons of soil catalase (A), acid phosphatase (B), and urease (C) activities between intercropping and monoculture. Values with same letters are not significantly different from each other within treatments at $\mathrm{P}=0.05$.

Addition: 1. Chinese cabbage monoculture; 2. cabbage monoculture; 3. intercropping.

the maximum levels allowed in foods which is $0.2 \mathrm{mg}$ $\mathrm{kg}^{-1} \mathrm{FW}$ (fresh weight) according to the China national standard for contaminants in foods (GB 2762-2017), indicating no health risk. Moreover, according to the national standard for soil contamination (GB 156182018), the potted soil used in our experiment is not suitable for crop cultivation, and the field soil used is needed to be cultivated under safety measures, but the low $\mathrm{Cd}$ accumulator cabbage reached the level of safe production through intercropping, and compared with monoculture, the biomass of Chinese cabbage increased (by 27.20 $\pm 5.26 \mathrm{~g}$ ) while cabbage had few alterations when intercropping (decreased by $5.87 \pm 3.08 \mathrm{~g}$ ). Thus, Cd extraction was advanced while safe production was obtained under this cultivation measure.

Co-cropping/intercropping of low-metal accumulators with metal high-accumulators have been shown to produce safe food and meanwhile to reduce the metal content in soil (WEI et al. 2005; ZHU et al. 2012). In the pre-experiment, when we used the same source of soil as this pot experiment (the physical and chemical properties were shown in Table 1) and the $\mathrm{Cd}$ content is added to $20 \mathrm{mg} \mathrm{kg}^{-1}$, Cd levels in shoots of Chinese cabbage and cabbage were determined to be $55.3 \mathrm{mg} \mathrm{kg}^{-1}$ and $12.1 \mathrm{mg} \mathrm{kg}^{-1}$, respectively. It also got the same result that the Chinese cabbage is a relatively high-accumulator of $\mathrm{Cd}$ while the cabbage is a relatively low-accumulator. In our experiment, differences in soil $\mathrm{Cd}$ values are not significantly between the several treatments, presumably due to our experimental materials (vegetables) used which have relatively lower biomass and relatively shorter growth period. It is likely that just one cycle of cultivation is not enough for remediation of the soil $\mathrm{Cd}$. However, there are many reports concerning plant materials either with high biomass (e.g. Sorghum bicolor (L.) Moench) or with the ability to remediate high level of toxic metals, known as hyperaccumulators. For example, some researchers used the toxic metal hyperaccumulator plants to achieve the rehabilitation of cadmiumcontaminated soil (VERBRUGGEN, 2009; SHAHID et al., 2012; FIDALGO et al., 2011). Usually, they still need a long planting period (within a few years) to achieve better restoration effect (TANG et al., 2017). The material with higher biomass, however, is often not suitable for intercropping with vegetables, since it can significantly affect the growth of vegetables.

In this paper, we aimed to test intercropping between vegetables to analyze their interactions to

Table 3 - Comparisons of soil pH (mean \pm SD) between intercropping and monoculture. Values with same letters are not significantly different from each other within treatments at $\mathrm{P}=0.05$.

\begin{tabular}{lc}
\hline Treatment & $\mathrm{pH}$ \\
\hline Non-planted soil & $5.76 \pm 0.07 a$ \\
Chinese cabbage monoculture & $5.49 \pm 0.05 b$ \\
Cabbage monoculture & $5.62 \pm 0.17 \mathrm{~b}$ \\
Intercropping & $5.59 \pm 0.03 \mathrm{~b}$ \\
\hline
\end{tabular}

Ciência Rural, v.49, n.11, 2019. 
each other on its $\mathrm{Cd}$ content regarding food safety. We found that intercropping can promote an increased Cd extraction in Chinese cabbage (a relatively highaccumulator of $\mathrm{Cd}$ ) and a decreased $\mathrm{Cd}$ extraction in cabbage (a relatively low-accumulator of $\mathrm{Cd}$ ). We supposed that the results may be the same in many other plant species. When a high-accumulator of $\mathrm{Cd}$ is intercropped with a low-accumulator plant, the $\mathrm{Cd}$ extraction by high-accumulator would increase while Cd extraction by low-accumulator would decrease. It was reported that when two different cultivars of cherry seedlings (Cd low accumulator) were intercropped with different ecotypes of Conyza canadensis (L.) Cronq. (Cd accumulator), Solanum nigrum L. (Cd hyperaccumulator), and Digitaria sanguinalis (L.) Scop. (Cd accumulator), similar results can be obtained (LIN et al., 2014). However, this hypothesis needs more experiments to be evaluated. Effect of intercropping on $\mathrm{Cd}$ accumulation is a particularly important issue to be considered in cultivation of vegetables in potentially contaminated land, because both two vegetables used would be consumed by us after harvest.

In addition, the availability of metals in the soil for plant uptake also affects plant absorption (BLAYLOCK et al., 1997). For example, Cd has limited solubility in soils and availability for plant uptake due to complexation with organic matter, sorption on oxides and clays, and precipitation as carbonates, hydroxides and phosphates. Level of exchangeable Cd in the contaminated soil was regarded as the best predictor for Cd uptake (MURAKAMI et al., 2008). Therefore, intercropping may alter the toxic metal extraction ability through the alteration of availability of toxic metal in soil. Availability of toxic metal is influenced by multiple factors. Firstly, a decrease in soil $\mathrm{pH}$ can increase the availability of toxic metals in soils and mobility of toxic metals in plants, due to precipitation reactions and increasing absorption (SELIM et al., 2005; CHARLESWORTH et al., 2016). Secondly, soil enzyme activity and toxic metals can interact with each other. For example, $\mathrm{Pb}$ contamination of soil produced a significant decrease in soil enzyme activities of urease, catalase, invertase, and acid phosphatase, and dehydrogenase has the most stimulatory effects on Cd activities (BELYAEVA et al., 2005; STUCZYNSKI et al., 2003). Thirdly, many organic acids exudate from in the roots of some plants can increase desorption of toxic metals, causing enhanced removability and exchangeability. For example, citric acid can increase the exchangeability of $\mathrm{Zn}$ and Cd (DING et al., 2014; SONG et al., 2016; JONES, 1998). Finally, rhizosphere microorganisms, such as Methylobacterium oryzae strain CBMB20 and
Burkholderia sp. strain CBMB40, have been reported to bind $\mathrm{Cd}$ in their growing and resting cells, resulting in decreased $\mathrm{Cd}$ accumulation in plants and subsequent reduced toxicity (MADHAIYAN et al., 2007).

In the pot experiment we evaluated the alteration of $\mathrm{Cd}$ fractions in soil, soil $\mathrm{pH}$, and soil enzymes activities between monoculture and intercropping. The soil $\mathrm{pH}$ has an important influence on the uptake of heavy metals by crops (ANDERSSON et al., 1974). Lower pH in soil has been widely observed to be responsible for higher $\mathrm{Cd}$ uptake of plants (SHAHID et al., 2012).

The present research showed that cultivation of Chinese cabbage, cabbage, and their intercropping decreased soil $\mathrm{pH}$. However, there were no significant differences of $\mathrm{pH}$ between the three different planting patterns. It is presumably due to the vegetables used which have relatively lower biomass and relatively shorter growth period through only one growth-cycle. Together, it suggested that $\mathrm{pH}$ value change is not the main reason for the changes in $\mathrm{Cd}$ content of these two vegetables in this experiment. Thus, a long-term experiment could be conducted to test if longer cultivation period (e.g. several rounds or years) can lead to significant alteration of the $\mathrm{pH}$ as well as $\mathrm{Cd}$ contents among the treatments (TANG et al., 2017).

Soil enzyme activity and toxic metals can interact with each other (SMOLINSKA et al. 2007). For example, maize intercropped with chick-pea resulted in enhanced acid phosphatase secretion by maize roots ( $\mathrm{LI}^{2}$ et al., 2004). We found that soil urease activity decreased significantly by Chinese cabbage monoculture, but not by cabbage monoculture. In intercropping of the two crops, however, urease activity also decreased significantly as that of Chinese cabbage (Figure 4C). It was reported that addition of synthetic urease into the contaminated soil significantly increased the accumulation of toxic metal (mercury) in garden cress plants (Lepidium sativum) (SMOLINSKA et al. 2007). Thus, alteration of $C d$ accumulation in cabbage was, at least in part, related to the alteration of urease activity. Soil urease activity may also work together with acid phosphatase to influence $\mathrm{Cd}$ accumulation in plants (STUCZYNSKI et al., 2003).

In Chinese cabbage monoculture, the easyabsorbable Cd fraction (exchangeable $\mathrm{Cd}$ ) was reduced significantly compared with that of non-planted soil after intercropping (Figure 3A). In a previous report, WANG et al. (2016) intercropped Luffa cylindrical and zinc/ cadmium hyperaccumulator Sedum plumbizincicola with $\mathrm{Cd}$ contaminated soil in a pot experiment, and reported that the available $\mathrm{Cd}$ content decreased 
significantly after intercropping. Because Chinese cabbage is a relatively high-accumulator of $\mathrm{Cd}$, the easy-absorbable $\mathrm{Cd}$ could be more easily extracted by Chinese cabbage in intercropping, resulting in the decrease of $\mathrm{Cd}$ accumulation in cabbage, reducing its health risk. Similar changes in soil $\mathrm{Cd}$ fractions under co-cropping/intercropping were also reported previously (LIN et al., 2014; TANG et al., 2017).

Our study did not cover the content of rhizosphere microorganism and organic acid secreted by roots. According to the reported studies, they also played important parts in Cd extraction (YANG et al., 2012). ZHAN et al. (2016) studied intercropping crops in the Huize lead-zinc mining area in Yunnan Province, Southwest China. It was reported that the major low molecular weight organic acids secreted by the roots of both $V$. faba and $S$. asper were oxalic acid, tartaric acid and citric acid, and there were significant negative correlations between the contents of citric acid, malic acid (secreted by $V$. faba roots), oxalic acid and tartaric acid (secreted by $S$. asper roots) and the available $\mathrm{Cd}$ content in the soil samples. Some rhizosphere microorganism may benefit to repair heavy toxic metal. LIU et al. (2017) reported that the majority of bacteria are inhibited by toxic metals, while sphingomonas bacteria are highly tolerant to heavy metals, thereby having the potential to repair heavy metal contamination. Soil grain size also affects soil microbial abundance and heavy metal adsorption in soil (SINGOVSZKA et al., 2015). Further experiments will be carried on these factors in our future study.

\section{CONCLUSION}

Intercropping can promote an increased $\mathrm{Cd}$ extraction in a relatively high-accumulator of $\mathrm{Cd}$ (Chinese cabbage) and a decreased $\mathrm{Cd}$ extraction in a relatively low-accumulator of $\mathrm{Cd}$ (cabbage). The alteration of $\mathrm{Cd}$ fractions and soil enzyme activities were similar between Chinese cabbage monoculture (six individuals) and intercropping (three individuals). The intercropping increased $\mathrm{Cd}$ extraction by Chinese cabbage and decreased $\mathrm{Cd}$ extraction by cabbage probably by influencing mechanisms such as soil enzyme activities (especially the urease activity) in the cultivation system. Effect of intercropping on $\mathrm{Cd}$ accumulation is an important issue in cultivation of vegetables in potentially contaminated land.

\section{ACKNOWLEDEMENGTS}

This research was supported by grants from the Key Research and Development Project of Zhejiang Province (2015C03020-4), the National Key Research and Development
Program of China (2017YFD0801104), Natural Science Foundation of Zhejiang Province (LQ18C020001), and Zhejiang University Student Science and Technology Innovation Activity Plan Project (2017R409044).

\section{DECLARATION OF CONFLICT OF INTERESTS}

The authors declare no conflict of interest. The founding sponsors had no role in the design of the study; in the collection, analyses, or interpretation of data; in the writing of the manuscript, and in the decision to publish the results.

\section{AUTHORS' CONTRIBUTIONS}

Cheng Zhu, Zhixiang Chen and Hexigeduleng Bao conceived and designed experiments. Jiayue Wan and Hexigeduleng Bao performed the experiments. Jiayue Wan performed statistical analyses of experimental data. Jiayue Wan, Hexigeduleng Bao, Lihong Huang, and Yanfei Ding prepared the draft of the manuscript. All authors critically revised the manuscript and approved of the final version.

\section{REFERENCES}

ABAYNEH, E. et al. Genesis and classification of sesquioxidic soils from volcanic rocks in sub-humid tropical highlands of Ethiopia. Geoderma, v.136, n.4-5, p.682-695, 2006. Available from: $<$ https://doi.org/10.1016/j.geoderma.2006.05.006>. Accessed: Sep. 12, 2019. doi: 10.1016/j.geoderma.2006.05.006.

ANDERSSON, A. et al. Influence of lime and soil ph on cd availability to plants. AMBIO. A Journal of the Human Environment, v.3(5), p.198-200, 1974. Available from: <https://www.researchgate.net/ publication/279893224_Influence_of_lime_and_soil_pH_on_Cd_ availability_to_plants $>$. Accessed: $\bar{S}$ Sep. 12, 2019.

BELYAEVA, O. N. et al. Barley yield and soil microbial and enzyme activities as affected by contamination of two soils with lead, zinc or copper. Biology and Fertility of Soils, v.41, n.2, p.85-94, 2005. Available from: <http://sci-hub.tw/10.1007/s00374-004-0820-9>. Accessed: Sep. 12, 2019. doi: 10.1007/s00374-004-0820-9.

BLAYLOCK, M. J. et al. Enhanced accumulation of $\mathrm{Pb}$ in Indian Mustard by soil-applied chelating agents. Environmental Science Technology, v.31, n.3, p.860-865, 1997. Available from: <http:// www.chemistry.armstrong.edu/nivens/Chem3300/phyto4.pdf $>$. Accessed: Sep. 12, 2019. doi: 10.1021/es960552a.

CHARLESWORTH, S. M. et al. An evaluation of the use of individual grass species in retaining polluted soil and dust particulates in vegetated sustainable drainage devices, Environmental Geochemistry and Health, v.38, n.4, p.973-985, 2016. Available from: <https://www. researchgate.net/publication/290219429_An_evaluation_of_the_use of_individual_grass_species_in_retaining_polluted_soil_and_dust_ particulates_in_vegetated_sustainable_drainage_devices $>$. Accessed: Sep. 12, 2019. doi: 10.1007/s10653-016-9791-7.

CHEN, D. et al. Human Health Risk Assessment of $\mathrm{Pb}$ and $\mathrm{Zn}$ in Farmland Soil of Shifang City. Journal of Agricultural Environmental Sciences, v.37, n.12, p.2687-2693, 2018. (in Chinese) Available from: $<$ https://max.book118.com/ html/2018/1222/5101104312001341.shtm>. Accessed: Sep. 12, 2019. doi: $10.11654 /$ jaes.2018-0108. 
DAMICONE, J. P. et al. Effects of border crops and intercrops on control of cucurbit virus diseases. Plant Disease, v.91, n.5, p.509-516, 2007. Available from: <https://apsjournals.apsnet.org/ doi/pdf/10.1094/PDIS-91-5-0509>. Accessed: Sep. 12, 2019. doi: 10.1094/PDIS-91-5-0509.

DING, Y.Z. et al. Interaction of organic acids and $\mathrm{pH}$ on multi-heavy metal extraction from alkaline and acid mine soils. International Journal of Environmental Science and Technology, v.11, p.3342, 2014. Available from: <http://www.ixueshu.com/document/8 369fb7c17c5c968318947a18e7f9386.html>. Accessed: Sep. 12, 2019. doi: 10.1007/s13762-013-0433-7.

FAO-Unesco. Soil Map of the World. 1: 5,000,000. Soil Science, v.112, n.2, p.132, 1973. Available from: <http://adsabs.harvard. edu/abs/1973SoilS.116..132>. Accessed: Sep. 12, 2019. doi: 10.1097/00010694-197308000-0001.

FASAHAT, P. Advances in Understanding of Cadmium Toxicity and Tolerance in Rice. Emirates Journal of Food and Agriculture, v.27, n.1, 2014. Available from: <https://www.directdomains.com/ profile/ejfa.info?domain=ejfa.info\&utm source=ejfa.info\&utm campaign $=$ directdomains_PRI\&traffic_id $=$ directdomains\&traffic type $=$ directdomains\&utm_medium $=$ click\&redirect $=$ dd-redirect $>$. Accessed: Sep. 12, 2019. doi: 10.9755/ejfa.v27i1.17870.

FIDALGO, F., et al. Solanum nigrum L. antioxidant defence system isozymes are regulated transcriptionally and posttranslationally in Cd-induced stress. Environmental and Experimental Botany, v.72, n.2, p.312-319, 2011. Available from: <https:// www.researchgate.net/publication/230888155_Solanum nigrum_L_antioxidant_defence_system_isozymes_are_regulated transcriptionally_and_posttranslationally_in_Cd-induced_stress $>$. Accessed: Sep. 12, 2019. doi: 10.1016/j.envexpbot.2011.04.007.

HUANG, Y. Z. et al. Absorption and accumulation of $\mathrm{Pb}, \mathrm{Cd}$ by corn, lupin and chickpea in intercropping systems. Acta Ecologica Sinica, v.26, n.5, p.1478-1485, 2006. Available from: <https:// www.researchgate.net/publication/287858706 Absorption and accumulation_of_Pb_Cd_by_corn_lupin_and_chickpea_in intercropping_systems $>$. Accessed: Sep. 12, 2019. doi: $10.1016 /$ S1872-2032(06)60005-X

JAISHANKAR, M. et al. Toxicity, mechanism and health effects of some heavy metals. Interdisciplinary Toxicology, v.7, n.2, p.60-72, 2014. Available from: <http://europepmc.org/ backend/ptpmcrender. fcgi?accid=PMC4427717\&blobtype $=$ pdf $>$. Accessed: Sep. 12, 2019. doi: 10.2478/intox-2014-0009.

JARUP, L. Hazards of heavy metal contamination. British Medical Bulletin, v.68, p.167-182, 2003. Available from: <https://www.semanticscholar.org/paper/ Hazards-of-heavy-metal-contamination.-J\%C3\%A4rup/ b117f7646eda7ef21889bbc0b222332d8e2324db>. Accessed: Sep. 12, 2019. doi: 10.1093/bmb/ldg032.

JOHNSON, J. L. et al. Some variables affecting the measurement of "catalase activity" in soil. Soil Sci. Soc. Am. Proc., v.28, p.207209, 1964. Available from: <https://www.soils.org/publications/ sssaj/abstracts/28/2/207>. Accessed: Sep. 12, 2019. doi: 10.2136/ sssaj 1964.03615995002800020024x.

JONES, D. L. Organic acids in the rhizosphere-a critical review. Plant and Soil, v.205, n.1, p.25-44, 1998. Available from: $<$ http://themodern.farm/studies/David\%20L.\%20Jones\%20 --\%20Organic\%20acids\%20in\%20the\%20rhizosphere\%20_\%20 a\%20critical\%20review.pdf $>$. Accessed: Sep. 12, 2019. doi: 10.1023/a:1004356007312.

LEFEBVRE, D. D. et al. Response to phosphate deprivation in Brassica nigra suspension cells: Enhancement of Intracellular, Cell Surface, and Secreted Phosphatase Activities Compared to Increases in Pi-Absorption Rate. Plant Physiology, v.93, p.504-511, 1990. Available from: <http://www.plantphysiol. org/content/93/2/504>. Accessed: Sep. 12, 2019. doi: 10.1104/ pp.93.2.504.

$\mathrm{LI}^{1}$, L. et al. Calcium, magnesium and microelement uptake as affected by phosphorus sources and interspecific root interactions between wheat and chickpea. Plant \& Soil, v.261, n.1-2, p.2937, 2004. Available from: <http://jpkc.scau.edu.cn/plantnutrition/ papers/upload/20076122139847177.pdf>. Accessed: Sep. 12, 2019. doi: 10.1023/b:plso.0000035579.39823.16.

$\mathrm{LI}^{2}$, S. M. et al. Acid phosphatase role in chickpea/maize intercropping. Annals of Botany, v.94, n.2, p.297-303, 2004. Available from: $<\mathrm{http} / / /$ europepmc.org/backend/ptpmcrender.fcgi ?accid=PMC4242165\&blobtype=pdf $>$. Accessed: Sep. 12, 2019. doi: $10.1093 / \mathrm{aob} / \mathrm{mch} 140$.

LIN, J. et al. Two ecotypes of hyperaccumulators and accumulators affect cadmium accumulation in cherry seedlings by intercropping. Environmental Progress \& Sustainable Energy, v.33, n.4, p.1251-1257,2014. Available from: $<$ https://www.researchgate.net/ publication/260305934_Two_Ecotypes_of_Hyperaccumulators and_Accumulators_Affect_Cadmium_Accumulation_in_Cherry Seedlings_by_Intercropping $>$. Accessed: Sep. 12, 2019. doi: 10.1002/ep.11924.

LIU, J. X., et al. Composition and Environmental Adaptation of Microbial Community in Shibahe Copper Tailing in Zhongtiao Mountain in Shanxi. Environmental Science, v.38(1), p.318326, 2017. (In Chinese) Available from: <http://www.cnki.com. $\mathrm{cn} /$ Article/CJFDTotal-HJKZ201701043.htm>. Accessed: Sep. 12, 2019. doi: 10.13227 /j.hjkx.201606201.

MADHAIYAN, M., et al. Metal tolerating methylotrophic bacteria reduces nickel and cadmium toxicity and promotes plant growth of tomato (Lycopersicon esculentum L.). Chemosphere, v.69, p.220-228, 2007. Available from: <https://www.researchgate.net/ publication/6320537_Metal_tolerating_methylotrophic_bacteria reduces_nickel_and_cadmium_toxicity_and_promotes_plant_ growth_of_tomato_Lycopersicon_esculentum_L $>$. Accessed: Sep. 12, 2019. doi: 10.1016/j.chemosphere.2007.04.017.

MURAKAMI, M. et al. Phytoextraction by a high-Cdaccumulating rice: reduction of $\mathrm{Cd}$ content of soybean seeds. Environmental Science \& Technology, v.42, p.6167-6172, 2008. Available from: <http://s3-eu-west-1.amazonaws.com/pstorageacs-6854636/4618870/es8001597_si_001.pdf >. Accessed: Sep. 12, 2019. doi: $10.1021 / \mathrm{es} 8001597$.

NANNIPIERI, P. The potential use of soil enzymes as indicators of productivity, sustainability and pollution. In: Pankhurst CE, Doube BM, Gupta VVSR, Grace PR (eds) Soil biota: management in sustainable farming systems. CSIRO, Victoria, Australia, p.238244, 1994. Available from: <https://www.mendeley.com/catalogue/ potential-soil-enzymes-indicators-productivity-sustainabilitypollution/>. Accessed: Sep. 12, 2019.

VERBRUGGEN, N. et al. Molecular mechanisms of metal hyperaccumulation in plants. New Phytologist, 
v.181, n.4, p.759-776, 2009. Available from: <https:// www.semanticscholar.org/paper/Molecular-mechanismsof-metal-hyperaccumulation-in-Verbruggen-Hermans/ c05bd64032d9f3b24eede056dfa88fbfdfba23b6>. Accessed: Sep. 12, 2019. doi: 10.1111/j.1469-8137.2008.02748.x.

POLACCO, J. C. et al. Structure and possible ureide degrading function of the ubiquitous urease of soybean. Plant Physiology, v.79, p.794-800, 1985. Available from: <http://www.plantphysiol. org/content/plantphysiol/79/3/794.full.pdf $>$. Accessed: Sep. 12, 2019. doi: 10.1104/pp.79.3.794.

REN, J. P. et al. Advances of the toxicology of cadmium. Acta zoonutrimenta sinica, v.15, n.1, p.1-6, 2003. Available from: $<$ http:// en.cnki.com.cn/Article_en/CJFDTOTAL-DWYX200301000.htm>. Accessed: Sep. 12, 2019.

SCHAEFER, G. L. et al. The USDA natural resources conservation service soil climate analysis network (SCAN). Journal of Atmospheric and Oceanic Technology, v.24, n.12, p.20732077, 2007. Available from: <http://wamis.org/agm/meetings/ etmner06/S2-Schaefer.pdf $>$. Accessed: Sep. 12, 2019. doi: 10.1175/2007JTECHA930.1.

SELIM, H. M. et al. Geochemical and Hydrological Reactivity of Heavy Metals in Soils. Soil Science, v.170, n.2, p.795, 2005. Available from: <https://journals.lww.com/soilsci/ Citation/2005/02000/Geochemical and Hydrological Reactivity_of_Heavy.8.aspx>. Accessed: Sep. 12, 2019. doi: 10.1097/00010694-200502000-00008.

SHAHID, M., et al. Long-Term Field Metal Extraction by Pelargonium: Phytoextraction Efficiency in Relation to Plant Maturity. International Journal of Phytoremediation, v.14, n.5, p.13, 2012. Available from: <https://www.researchgate.net/profile/ Anne_Probst/publication/224923939_Long-Term_Field_Metal_ Extraction by Pelargonium Phytoextraction Efficiency in Relation_to_Plant_Maturity/links/53f8f5950cf24ddba7db5a32/ Long-Term-Fie-1d-Metal-Extraction-by-PelargoniumPhytoextraction-Efficiency-in-Relation-to-Plant-Maturity.pdf $>$. Accessed: Sep. 12, 2019. doi: 10.1080/15226514.2011.604689.

SONG, Y. et al. Inhibition of low molecular organic acids on the activity of acidithiobacillus species and its effect on the removal of heavy metals from contaminated soil. Environmental Science, v.37, n.5, p.1960-1967, 2016. Available from: <http://en.cnki.com. cn/Article_en/CJFDTotal-HJKZ201605049.htm>. Accessed: Sep. 12, 2019. doi: 10.13227/j.hjkx.2016.05.046.

SINGOVSZKA, E. et al. The Effect of Sediment Grain Size on Heavy Metal Content in Different Depth in Water Reservoir Ruzin, Slovakia. Solid State Phenomena, v.244, p.240-245, 2015. Available from: <http://www.sci-hub.tw/10.4028/www.scientific. net/ssp $>$. Accessed: Sep. 12, 2019. doi: 10.4028/www.scientific. net/ssp. 24

STUCZYNSKI, T. I. et al. Response of soil microbiological activities to Cadmium, Lead, and Zinc salt amendments. Journal of Environmental Quality, v.32, p.1346-1355, 2003. Available from: <https://naldc.nal.usda.gov/download/59961/ PDF $>$. Accessed: Sep. 12, 2019. doi: 10.2134/jeq2003.1346.

SZUMIGALSKI, A. R. et al. Nitrogen yield and land use efficiency in annual sole crops and intercrops. Agronomy Journal, v.98, n.4, p.1030-1040, 2006. Available from: <http://www.beefresearch $\mathrm{ca} /$ research/foragebeef-website.cfm?utm_campaign=foragebeef.
ca\&utm_medium=Redirect\&utm_source=/\$Foragebeef/frgebeef. nsf/all/frg4593/\$FILE/efficiency.pdf>. Accessed: Sep. 12, 2019. doi: 10.2134/agronj2005.0277.

ELSAS, J.D.V. Methods of soil analysis. Part 2 - Microbiological and biochemical properties, Scientia Horticulturae, v.63, n.1, p.131-133, 1995. Available from: <http://www.>. Accessed: Sep. 12, 2019. doi: 10.1016/0304-4238(95)90023-3.

TANG, L. et al. Field crops (Ipomoea aquatica Forsk. and Brassica chinensis L.) for phytoremediation of cadmium and nitrate cocontaminated soils via rotation with Sedum alfredii Hance. Environmental Science and Pollution Research, v.24, n.23, p.19293-19305, 2017. Available from: <https://manuscriptpro. com/profile/tag/Ipomoea $>$. Accessed: Sep. 12, 2019. doi: 10.1007/ s11356-017-9146-7.

TESSIER, A. et al. Sequential extraction procedure for the speciation of particulate trace metals. Analytical Chemistry, v.51, n.7, p.844-851, 1979. Available from: <https://soils.ifas.ufl edu/lqma/SEED/CWR6252/Handout/Handout-10.pdf>. Accessed: Sep. 12, 2019. doi: 10.1021/ac50043a017.

TYLER, G. Heavy metal pollution and soil enzymatic activity. Plant and Soil, v.41, n.2, p.303-311, 1974. Available from: $<$ https://eurekamag.com/research/000/106/000106570.php>. Accessed: Sep. 12, 2019. doi: 10.1007/BF00017258.

WANG, J. et al. Computer-simulated evaluation of possible mechanisms for quenching heavy metal ion activity in plant vacuoles I. Cadmium. Plant Physiology, v.97, p.1154-1160, 1991. Available from: <http://www.plantphysiol.org/content/ plantphysiol/99/2/621.full.pdf $>$. Accessed: Sep. 12, 2019. doi: $10.2307 / 4273962$.

WANG, J. W. et al. Investigating the intercropping effects of Sedum plumbizincicola and Luffa cylindrical on soil cadmium fractions and cadmium uptake by Luffa cylindrical. Journal of AgroEnvironment Science, v.35, n.12, p.2292-2298, 2016. Available from: $\quad<$ http://www.aes.org.cn/nyhjkxxb/ch/reader/create_pdf. aspx?file_no=20161207\&flag=1\&journal_id=nyhjkxxb\&year $\mathrm{id}=2016>$. Accessed: Sep. 12, 2019. doi: 10.11654/jaes.2016-0825.

WEI, Z.B. et al. Phytoremediation of heavy metal contaminated soil with mixed chelators in co-crop system. Journal of AgroEnvironment Science, v.24, n.6, p.1262-1263, 2005. Available from: <https:/www.ixueshu.com/document/45a38ce2610d366e31 8947a18e7f9386.html>. Accessed: Sep. 12, 2019. doi: 10.3321/j. issn:1672-2043.2005.06.045.

WU, H. J. et al. The influence of interspecific interactions on $\mathrm{Cd}$ uptake by rice and wheat intercropping. Journal of Agricultural Science and Technology, v.5, n.5, p.43-46, 2003. Available from: $<$ http://www.cqvip.com/Main/Detail.aspx?id=8554268>. Accessed: Sep. 12, 2019. doi: 10.3969/j.issn.1008-0864.2003.05.010.

XIN, Y. et al. Effects of AMF inoculation on maize and soybean interspecific competition of $\mathrm{N}$ uptake on red soil under intercropping condition. Mycosystema, v.36, n.7, p.972-982, 2017. Available from: <http:/www.wanfangdata.com.cn/details/ detail.do? type $=$ perio\&id $=$ jwxt201707016 $>$. Accessed: Sep. 12, 2019. doi: $10.13346 /$ j.mycosystema. 170064 .

YANG, T. Y. et al. Rhizosphere microbial communities and organic acids secreted by aluminum-tolerant and aluminum-sensitive soybean in acid soil. Biology \& Fertility of Soils, v.48, n.1, p.97-108, 2012. 
Available from: $<$ https://www.researchgate.net/publication/251320970_ Rhizosphere microbial communities and organic acids secreted by_aluminum-tolerant_and_aluminum-sensitive_soybean_in_acid_ soil $>$. Accessed: Sep. 12, 2019. doi: 10.1007/s00374-011-0608-7.

YUAN, Y. X. et al. A review of research in agroforestry of the world. World Forestry Research, v.11, n.5, p.26-31, 1998. Available from: <http://en.cnki.com.cn/Article_en/CJFDTOTALSJLY805.004.htm>. Accessed: Sep. 12, 2019.

YUAN, Z. Y. et al. Effect of soil grain size gradation on sorption and desorption of cadmium. Chinese Journal of Environmental Engineering, v.7, n.5, p.1979-1983, 2013. Available from: $<$ https://www.ixueshu.com/document/975a847252c1746c318947a 18e7f9386.html>. Accessed: Sep. 12, 2019.
ZHAN, F. et al. Cadmium and lead accumulation and lowmolecular-weight organic acids secreted by roots in an intercropping of a cadmium accumulator Sonchus asper L. with Vicia faba L. RSCAdvances, v.6, n.40, p.33240-33248, 2016. Available from: <https://pubs.rsc.org/en/content/articlelanding/2016/RA/ C5RA26601G\#!divAbstract>. Accessed: Sep. 12, 2019. doi: $10.1039 / \mathrm{c} 5 \mathrm{ra} 26601 \mathrm{~g}$.

ZHU, Z. et al. Bioremediation of Cd-DDT co-contaminated soil using the Cd-hyperaccumulator Sedum alfredii and DDT degrading microbes. Journal of Hazardous Materials, v.235, p.144151, 2012. Available from: <https://www.semanticscholar.org/ paper/Bioremediation-of-Cd-DDT-co-contaminated-soil-usingZhu-Yang/a59b2c65810c924106c59f305dbbf477b861e965>. Accessed: Sep. 12, 2019. doi: 10.1016/j.jhazmat.2012.07.033. 


\section{Erratum}

In the article " Soil cadmium extraction in Chinese cabbage and cabbage intercropping" published in Ciência Rural, volume 49, number 11, DOI http://dx.doi.org/10.1590/01038478 cr20190279.

Where we read:

\section{AUTHORS' CONTRIBUTIONS}

Cheng Zhu, Zhixiang Chen and Hexigeduleng Bao conceived and designed experiments. Jiayue Wan and Hexigeduleng Bao performed the experiments. Jiayue Wan performed statistical analyses of experimental data. Jiayue Wan, Hexigeduleng Bao, Lihong Huang, and Yanfei Ding prepared the draft of the manuscript. All authors critically revised the manuscript and approved of the final version.

Read:

\section{AUTHORS' CONTRIBUTIONS}

Cheng Zhu, Zhixiang Chen and Hexigeduleng Bao conceived and designed experiments. Jiayue Wan and Hexigeduleng Bao performed the experiments. Jiayue Wan performed statistical analyses of experimental data. Jiayue Wan, Hexigeduleng Bao, Lihong Huang, and Yanfei Ding prepared the draft of the manuscript. All authors critically revised the manuscript and approved of the final version. Jiayue Wan and Hexigeduleng Bao contributed equally for the paper and should be considered both first authors. 